\title{
Nutrient removal by apple, pear and cherry nursery trees
}

\author{
Giovambattista Sorrenti, ${ }^{1}$ Maurizio Quartieri, ${ }^{1}$ Silvia Salvi, ${ }^{2}$ Moreno Toselli ${ }^{1}$ \\ ${ }^{1}$ Department of Agricultural Sciences, University of Bologna, Bologna; ${ }^{2}$ Agricultural Company Salvi Vivai \\ S.S., Ferrara, Italy
}

\begin{abstract}
Given that nursery is a peculiar environment, the amount of nutrients removed by nursery trees represents a fundamental acquisition to optimise fertilisation strategies, with economic and environmental implications. In this context, we determined nutrient removal by apple, pear and cherry nursery trees at the end of the nursery growing cycle. We randomly removed 5 leafless apple (Golden Delicious/EMLA M9; density of 30,000 trees ha ${ }^{-1}$ ), pear (Santa Maria/Adams; density of 30,000 trees ha ${ }^{-1}$ ) and cherry $\left(\right.$ Alex ${ }^{\mathrm{TM}} /$ Gisela $^{\circledR}{ }^{\circledR}$; density of 40,000 trees $^{-1} \mathrm{a}^{-1}$ ) trees from a commercial nursery. Trees were divided into roots (below the root collar), rootstock (above-ground wood between root collar and grafting point) and variety (1-year-old wood above the grafting point). For each organ we determined biomass, macro- (N, P, K, Ca, Mg, $\mathrm{S}$,) and micro- (Fe, $\mathrm{Mn}, \mathrm{Zn}, \mathrm{Cu}$, and $\mathrm{B})$ nutrient concentration. Pear trees were the most developed $\left(650 \mathrm{~g}(\mathrm{dw})\right.$ tree $^{-1}$, equal to 1.75 and 2.78 folds than apple and cherry trees, respectively) whereas, independently of the species, variety mostly contributed $(>50 \%)$ to the total tree biomass, followed by roots and then above-ground rootstock. However, the dry biomass and nutrient amount measured in rootstocks (including roots) represent the cumulative amount of 2 and 3 seasons, for Gisela ${ }^{\circledR} 6$ (tissue culture) and pome fruit species (generated by mound layering), respectively. Macro and micronutrients were mostly concentrated in roots, followed by variety and rootstock, irrespective of the species. Independently of the tissue, macronutrients concentration
\end{abstract}

Correspondence: Giovambattista Sorrenti, Department of Agricultural Sciences, University of Bologna, viale G. Fanin 44, 40127 Bologna, Italy.

Tel: +39.051.2096426 - Fax: +39.051.2096401.

E-mail: g.sorrenti@unibo.it

Key words: Fertilisation; Gisela; Golden Delicious; Iron; Nitrogen.

Acknowledgments: the authors thank the anonymous reviewer for the valuable comments that helped to improve the manuscript.

Received for publication: 19 June 2016.

Revision received: 8 November 2016.

Accepted for publication: 1 December 2016.

(C) Copyright G. Sorrenti et al., 2017

Licensee PAGEPress, Italy

Italian Journal of Agronomy 2017; 12:805

doi:10.4081/ija.2016.805

This article is distributed under the terms of the Creative Commons Attribution Noncommercial License (by-nc 4.0) which permits any noncommercial use, distribution, and reproduction in any medium, provided the original author(s) and source are credited. hierarchy was $\mathrm{N}>\mathrm{Ca}>\mathrm{K}>\mathrm{P}>\mathrm{Mg}>\mathrm{S}$. Removed $\mathrm{N}$ by whole tree accounted for $6.58,3.53$ and $2.49 \mathrm{~g}$ tree $^{-1}$ for pear, apple and cherry, respectively, corresponding to almost 200, 107 and $100 \mathrm{~kg} \mathrm{~N}$ $\mathrm{ha}^{-1}$, respectively. High amounts of $\mathrm{K}$ and $\mathrm{Ca}$ were used by pear (130-140 kg ha $\left.{ }^{-1}\right)$ and apple trees $\left(\sim 50\right.$ and $130 \mathrm{~kg} \mathrm{ha}^{-1}$ of $\mathrm{K}$ and $\mathrm{Ca}$, respectively), while $25 \mathrm{~kg} \mathrm{~K} \mathrm{ha}^{-1}$ and $55 \mathrm{~kg} \mathrm{Ca} \mathrm{ha}^{-1}$ were calculated for cherry nursery trees. Among micronutrients, Fe was the most required $\left(\sim 3 \mathrm{~kg} \mathrm{ha}^{-1}\right)$ independently of the species. B removal ranged between 1.2 and $2.4 \mathrm{~kg} \mathrm{ha}^{-1}$ (80, 40 and $30 \mathrm{mg}$ tree $^{-1}$ for pear, apple and cherry, respectively), whereas $\mathrm{Mn}, \mathrm{Cu}$ and $\mathrm{Zn}$ accounted for few hundred $\mathrm{g} \mathrm{ha}^{-1}$, irrespective of the species. Given that nutrient concentration among tissues resulted within the same order of magnitude, irrespective of the species, differences in removal were mainly driven by the tree biomass as proved by the significant correlations between plant dry biomass with most of the nutrients we observed.

\section{Introduction}

High-quality young trees represent an essential prerogative in commercial orchards (Kaplan and Baryla, 2006) in order to reduce the non-bearing phase. Fruit trees are usually commercially distributed after a two- three-year nursery growing cycle and graft is mostly adopted for trees designed for intensive orchards. Cultivars are frequently budded on late summer onto 1- 2-year-old rootstocks, which are in turn obtained by seeds, mound layering, trench layering, hardwood cutting or micropropagation. The following season, grafted trees are carefully managed in terms of irrigation and fertilisation to produce an upright leader provided by consistent lateral branches (Bielicki et al., 2002). At the end of the nursery growth cycle, trees should be adequately developed with favorable size and root:shoot ratio. Additionally, young trees must accumulate high levels of reserves [carbohydrates and nitrogen (N)] to support the new growth until photosynthesis and mineral root uptake can sustain plant metabolism (Millard, 1995).

To ensure optimal growing conditions, fertilisation of maiden or grafted trees plays a crucial role in the nursery (Timmer and Aidelbaum, 1996; Malik and Timmer, 1998; Neto et al., 2008). Nevertheless, nursery is a peculiar growth environment characterised by: i) sandy and poorly structured soils to limit root damages during mechanical tree removal; ii) ultra-high planting density (often $>40.000$ trees ha $^{-1}$ ) to best use soil surface and optimise the agronomic management (irrigation, fertilisation, pest and diseases control); iii) high competition among tree roots as a consequence of the high planting density and soil texture. As outcome, nursery trees are more dependent on the mineral uptake than mature trees because of their smaller root size, limited storage reservoirs and reduced vegetative growth ( $\mathrm{Bi}$ et al., 2004). Therefore, with the aim to promote a fast growth, generous fertilisation rates and irrigation volumes are sometimes adopted (Castle and Rouse, 1990) in commercial nurseries. 
As a result, the amount of nutrients supplied during nursery phase may be in excess compared to the quantities effectively removed by crops, as described in a survey for forestry species recorded in North America, Britain and Germany (van den Driessche, 1980). Similarly to mature orchards, the amount of nutrients removed by different species in the nursery is a basic knowledge to optimise fertilisation strategies, as this has both economical and environmental implications. van den Driessche (1980) reported that amount of nutrients removed by conifer nursery crops ranged between 50 and $200 \mathrm{~kg} \mathrm{~N} \mathrm{ha}^{-1}, 4$ and $35 \mathrm{~kg}$ phosphorus $(\mathrm{P}) \mathrm{ha}^{-1}, 25$ and $105 \mathrm{~kg}$ potassium $(\mathrm{K}) \mathrm{ha}^{-1}$. However, information about nutrient removal of temperate perennial crops during the nursery growth period are still lacking.

The eastern Po valley (Italy) is a region traditionally well known for the importance of the nursery industry, which generates consistent income. For instance, over than 32 millions of woody fruit trees (including rootstocks and excluding berries) were produced in 2014 (Civi-Italia, 2015), mainly exported.

Therefore, the objective of this study was to quantify the mineral nutrient removal and partitioning among organs by apple, pear and cherry trees at the end of the nursery growth phase. These acquisitions may serve to optimise fertilisation strategies for the three species in temperate regions with potential economic and environmental positive implications.

\section{Materials and methods}

At the end of the growing nursery phase (winter, 2015), five leafless apple (cv. Golden Delicious Malus domestica B. grafted on M9 EMLA), pear (cv. Santa Maria Pyrus communis L. grafted on quince Adams Cydonia oblonga M.) and cherry (cv. Alex ${ }^{\mathrm{TM}}$ Prunus avium L. grafted on Gisela ${ }^{\circledR} 6$ Prunus cerasus L. $x$ Prunus canescens B.) trees were randomly removed from a commercial nursery (Salvi Vivai s.s.) located in the Italian eastern [Lagosanto (FE)] Po Valley (44 $80^{\prime} \mathrm{N} 12^{\circ} 17^{\prime} \mathrm{E}$; $0 \mathrm{~m}$ a.s.l.). The region has a temperate sub-continental climate with cold winters, humid and warm summers, mainly without dry seasons. The average temperature of the area is $23.4^{\circ} \mathrm{C}$, rarely below $-6^{\circ} \mathrm{C}$ or above $36^{\circ} \mathrm{C}$. Yearly precipitations are generally below $800 \mathrm{~mm}$, mostly concentrated in spring and autumn.

The nursery was open-field and the main soil physical and chemical characteristics are summarised in Table 1.

When removed, pear trees (1.80 $\mathrm{m}$ tall) were characterised by abundant and well-developed ( $>5$ ) lateral branches, uniformly distributed along the central leader. Cherry trees consisted of a tall $(>2$ $\mathrm{m})$ leader $(\sim 20 \mathrm{~mm} \emptyset)$, laterally devoid by any branch but covered with newly differentiated buds, as usually observed for young nursery sweet cherry trees in other environments (Moghadam and Zamanipour 2013). Apple trees were characterised by a $\sim 1.7 \mathrm{~m}$ tall central leader with few ( 1-3) and poorly developed lateral branches. In late summer (2014), trees were budded (Chip-budding technique) in the field at about $100-150 \mathrm{~mm}$ above the ground level and the planting distance was $0.33 \mathrm{~m} \times 1 \mathrm{~m}, 0.33 \mathrm{~m} \times 1 \mathrm{~m}$ and $0.25 \mathrm{~m}$ $\times 1 \mathrm{~m}$ (equal to densities of 30,000,30,000 and 40,000 trees ha ${ }^{-1}$ ) for apple, pear and cherry, respectively. Trees were irrigated by a one-line drip irrigation lying on the ground of each row from May through September with volumes up to $5 \mathrm{~mm}$ for each watering (full summer), according to the evapotranspiration rates. Approximately, yearly irrigation volumes were equal to $3000 \mathrm{~m}^{3}$ $\mathrm{ha}^{-1}$. Before the nursery establishment, the soil was amended with organic matter while during the growing season trees received $\mathrm{N}$,
$\mathrm{P}$ and $\mathrm{K}$ mineral inputs at rates of 120,90 and $75 \mathrm{~kg} \mathrm{ha}^{-1}$, respectively. Microelements, mostly iron (Fe) were also periodically distributed. Fertilisers were supplied through fertigation. Weeds were mechanically removed at the beginning of the season, while herbicides were then used. Commercially available chemical pesticides were repeatedly sprayed over the tree canopy to control pests (i.e. pear psylla, aphids, codling moth, mites, pandemis etc.) and diseases (i.e. brown spot, apple scab, Monilinia, powdery mildew, bacterial canker, coryneum, etc.).

Harvested trees were divided into roots (below the root collar), rootstock (above-ground wood between root collar and grafting point) and variety (wood above the grafting point). While the latest organ was 1-year-old independently of the species, rootstocks (including roots) of cherry and pome fruit trees were 2 and 3-year old, respectively, as Gisela ${ }^{\circledR} 6$ was obtained by tissue culture (in vitro) while M9 and quince Adams rootstocks were generated by mound layering.

Total fresh weight of each organ was recorded, then subsamples per tree were oven-dried at $65^{\circ} \mathrm{C}$ until constant weight and milled $(<0.5 \mathrm{~mm}$ mesh) (Pulverisette 14, Fritsch $\mathrm{GmbH}$, IdarOberstein, Gemany).

Macro $[\mathrm{N}, \mathrm{P}, \mathrm{K}$, calcium $(\mathrm{Ca})$, magnesium $(\mathrm{Mg})$, sulphur $(\mathrm{S})]$ and micro $[\mathrm{Fe}$, manganese $(\mathrm{Mn})$, zinc $(\mathrm{Zn})$, copper $(\mathrm{Cu})$ and boron (B)] nutrient concentration was determined on each individual tissue. $\mathrm{N}$ was determined by the Kjeldahl method (Schuman et al., 1973) by mineralising $1.0 \mathrm{~g}$ (d.w.) with $10 \mathrm{~mL}$ of a $95: 5\left(\mathrm{v} \mathrm{v}^{-1}\right)$ sulphuric acid:phosphoric acid $\left(\mathrm{H}_{2} \mathrm{SO}_{4}: \mathrm{H}_{3} \mathrm{PO}_{4}\right)$ mixture at $420^{\circ} \mathrm{C}$ for $180 \mathrm{~min}$ and subsequent distillation with $32 \%\left(\mathrm{v} \mathrm{v}^{-1}\right)$ sodium hydroxide $(\mathrm{NaOH})$ and titration with $0.1 \mathrm{~N} \mathrm{H}_{2} \mathrm{SO}_{4}$.

$\mathrm{P}, \mathrm{S}, \mathrm{B}$ and metals (K, Ca, Mg, Fe, $\mathrm{Cu}, \mathrm{Zn}$ and $\mathrm{Mn}$ ) were determined by inductively coupled plasma optical emission spectroscopy (ICP-OES), (Ametek Spectro Arcos EOP, Kleve, Germany), after digestion with nitric acid $\left(\mathrm{HNO}_{3}\right)$ (Kingston, 1988) by a microwave lab station (Ethos TC-Milestone, Bergamo, Italy).

The amount of nutrients removed by organs was calculated multiplying the mineral concentration by the organ dry weight. The amount of minerals removed by each tree was obtained by adding the fractions of the three organs. Per each species, we estimated the amount of minerals removed by 1 ha of nursery, according to the relative tree density.

\section{Statistical analyses}

Coefficient of determination $\left(\mathrm{R}^{2}\right)$ between dry biomass and nutrient removed by whole trees was calculated using linear regression analysis. Data were submitted to analysis of variance using PROC MIXED with a compound symmetry covariance structure, according to a randomised experimental design with 5 replicates. When analysis of variance among the three species showed a statistical effect, means were separated by Tukey's honest significant difference test (at $\mathrm{P} \leq 0.05$ ). Statistical analyses were performed by using SAS 9.0 software (SAS Institute Inc., Cary, NC, USA). Within nutrients, confidence interval at 95\% $\left({ }_{95} \mathrm{CI}\right)$ was calculated for each means and represented in column.

\section{Results}

Young pear trees accounted for the highest wood canopy and root dry weight, whereas values between the other two species were statistically comparable (Figure 1). The dry weight of the apple rootstock was higher than cherry and pear trees and within 
each species, the wood variety mostly contributed ( $>50 \%)$ to the total tree biomass, followed by roots and then above-ground rootstock (Figure 1). The pear root biomass was 2-time higher than the other species and the above:below the grafting point wood ratio was $1.25,1.36$ and 1.59 for cherry, apple and pear trees, respectively. Total pear tree biomass accounted for almost $650 \mathrm{~g} \mathrm{tree}^{-1}$, equal to 1.75 and 2.78 times that of apple and cherry trees, respectively. The latter species showed the lowest total dry weight, slightly over $230 \mathrm{~g}^{\text {tree }}{ }^{-1}$ (Figure 1).

Independently of the species, macro and micronutrients were overall mostly concentrated in roots, followed by variety and finally by the above-ground portion of the rootstock (Table 2). Only the concentration of $\mathrm{Fe}$ and, to a less extent $\mathrm{Mn}$, was higher in rootstock than in the wood variety. With the exception of $\mathrm{Ca}$ in the rootstock, $\mathrm{N}$ was the most concentrated element in all tissues, followed by Ca, K, P, Mg and S (Table 2). The concentration of $\mathrm{N}$ was highest in cherry roots whilst those of $\mathrm{Mg}$ and $\mathrm{K}$ were higher in tissues of pear trees (Table 2). Among micronutrients, Fe was the most abundant, followed by $\mathrm{B}, \mathrm{Mn}, \mathrm{Cu}$ and $\mathrm{Zn}$, irrespective of the organ and species (Table 2).

Within species, the amount of macronutrients removed followed this order: $\mathrm{N}>\mathrm{Ca}>\mathrm{K}>\mathrm{P}>\mathrm{Mg}>\mathrm{S}$ (Figure 2). Pear trees removed higher amounts of macronutrients compared to cherry and, with the exception of $\mathrm{Ca}$ and $\mathrm{S}$, to apple. Unless for $\mathrm{N}$ and $\mathrm{Mg}$, apple removed higher amounts of nutrients than cherry (Figure 2). In details, the amount of $\mathrm{N}$ removed by whole trees was in average $6.58,3.53$ and $2.49 \mathrm{~g}$ for pear, apple and cherry, respectively (Figure 2). Considerable amounts $\left(>1 \mathrm{~g}^{\text {tree }}{ }^{-1}\right)$ were also calculated for $\mathrm{Ca}$ and $\mathrm{K}$, while less than $1 \mathrm{~g}$ tree $^{-1}$ was measured for $\mathrm{P}, \mathrm{Mg}$ and $\mathrm{S}$, independently of the species (Figure 2).

Within micronutrients, removal followed the order $\mathrm{Fe}>\mathrm{B}>\mathrm{Cu}>\mathrm{Mn}>\mathrm{Zn}$. Fe was the most removed nutrient accounting for 121,101 and $62 \mathrm{mg}^{-1} \mathrm{e}^{-1}$ for pear, apple and cherry, respectively (Figure 3). Removed micronutrients resulted always higher in pear compared to cherry trees and with the exception of Fe and $\mathrm{Mn}$, also compared with apple (Figure 3). Apple trees removed higher amount of $\mathrm{Mn}, \mathrm{Cu}$ and $\mathrm{Zn}$ than cherry, while comparable values were measured for Fe and B (Figure 3).

Table 3 reports, within each species, correlation parameters between total mineral removal and plant dry biomass. Pooling data of the 3 species, a linear significant $(\mathrm{P}<0.0001)$ correlation between total $\mathrm{N}$ and plant dry biomass was observed, with an $\mathrm{R}^{2}=0.97$ (Figure 4).

Considering 1 ha nursery, despite the higher planting density of the cherry trees $(+33 \%$ than apple and pear), the amount of removed nutrients mirrored that of individual tree (Figures 5 and 6). In fact, pear was the most nutrient demanding species in the nursery, then apple and cherry, either for macro and micronutrients (Figures 5 and 6). $\mathrm{N}$ was the most absorbed nutrient and pear trees removed slightly less than $200 \mathrm{~kg} \mathrm{~N} \mathrm{ha}^{-1}$ while apple and cherry trees removed 107 and $100 \mathrm{~kg} \mathrm{~N} \mathrm{ha}^{-1}$ (Figure 5), respectively. Similarly to N, high amounts of $\mathrm{K}$ and $\mathrm{Ca}$ were used by pear $\left(\sim 130-140 \mathrm{~kg} \mathrm{ha}^{-1}\right)$ and apple trees $\left(\sim 50\right.$ and $130 \mathrm{~kg} \mathrm{ha}^{-1}$ of $\mathrm{K}$ and $\mathrm{Ca}$, respectively) while $\sim 25 \mathrm{~kg} \mathrm{~K} \mathrm{ha}^{-1}$ and $55 \mathrm{~kg} \mathrm{Ca} \mathrm{ha}^{-1}$

Table. 1. Main chemical and physical characteristics of the soil of the nursery (average \pm standard error; $n=3$ ).

\begin{tabular}{|c|c|}
\hline Parameter & Value \\
\hline Coarse sand ( $\left(\mathrm{g} 100 \mathrm{~g}^{-1}\right)$ & $41.5 \pm 4.4$ \\
\hline Fine sand $\left(\mathrm{g} 100 \mathrm{~g}^{-1}\right)$ & $36.5 \pm 4.4$ \\
\hline Coarse silt $\left(\mathrm{g} 100 \mathrm{~g}^{-1}\right)$ & $5.5 \pm 1.8$ \\
\hline Fine silt $\left(\mathrm{g} 100 \mathrm{~g}^{-1}\right)$ & $9.6 \pm 3.4$ \\
\hline Lime $\left(\mathrm{g} 100 \mathrm{~g}^{-1}\right)$ & $6.9 \pm 6.1$ \\
\hline Organic matter $\left(\mathrm{g} 100 \mathrm{~g}^{-1}\right)$ & $2.2 \pm 0.7$ \\
\hline $\mathrm{pH}$ & $7.6 \pm 0.2$ \\
\hline Electrical conductivity $\left(\mu \mathrm{S} \mathrm{cm}{ }^{-1}\right)$ & $195 \pm 30$ \\
\hline CEC (meq $100 \mathrm{~g}^{-1}$ ) & $16.3 \pm 1.8$ \\
\hline Total $\mathrm{CaCO}_{3}\left({\left.\mathrm{~g} 100 \mathrm{~g}^{-1}\right)}^{-1}\right.$ & $7.9 \pm 2.4$ \\
\hline Active lime $\left(\mathrm{CaCO}_{3}\right)\left(\mathrm{g} 100 \mathrm{~g}^{-1}\right)$ & $3.2 \pm 1.0$ \\
\hline$N\left(g 100 g^{-1}\right)$ & $0.11 \pm 0.03$ \\
\hline $\mathrm{C} / \mathrm{N}$ & $11.6 \pm 4.7$ \\
\hline Organic C (g $\left.100 \mathrm{~g}^{-1}\right)$ & $1.28 \pm 0.4$ \\
\hline Available P (mg kg-1) & $204 \pm 9.4$ \\
\hline Exchangeable K $\left(\mathrm{mg} \mathrm{kg}^{-1}\right)$ & $330 \pm 52$ \\
\hline Exchangeable $\mathrm{Mg}\left(\mathrm{mg} \mathrm{kg}^{-1}\right)$ & $102 \pm 42$ \\
\hline
\end{tabular}

CEC, cation exchange capacity.

Table 2. Mineral concentration of roots, rootstock and variety of nursery cherry, apple and pear trees at the end of the growing phase.

\begin{tabular}{|c|c|c|c|c|c|c|c|c|c|c|c|}
\hline & $\mathbf{N}$ & $\mathbf{P}$ & $\mathrm{K}$ & $\mathrm{Ca}$ & Mg & S & $\mathrm{Fe}$ & Mn & $\mathrm{Cu}$ & $\mathrm{Zn}$ & B \\
\hline Roots & \multicolumn{8}{|c|}{$\left(g \mathrm{DW} \mathrm{kg}{ }^{-1}\right)$} & \multicolumn{3}{|c|}{$\left(\mathrm{mg} \mathrm{DW} \mathrm{kg}^{-1}\right)$} \\
\hline Cherry & $14.8^{\mathrm{a}}$ & 1.25 & $3.09^{c}$ & $9.72^{\mathrm{ab}}$ & $1.05^{\mathrm{b}}$ & $0.66^{\mathrm{b}}$ & $1006^{\mathrm{a}}$ & $20.7^{\mathrm{ab}}$ & $10.5^{\mathrm{ab}}$ & $10.5^{b}$ & $143.5^{\mathrm{a}}$ \\
\hline Apple & $13.2^{\mathrm{b}}$ & 1.18 & $4.19^{b}$ & $13.2^{\mathrm{a}}$ & $1.26^{\mathrm{a}}$ & $1.06^{\mathrm{a}}$ & $783^{\mathrm{ab}}$ & $33.0^{\mathrm{a}}$ & $10.0^{\mathrm{b}}$ & $20.3^{\mathrm{a}}$ & $118.1^{\mathrm{b}}$ \\
\hline Pear & $11.9^{c}$ & 1.40 & $6.14^{\mathrm{a}}$ & $8.27^{\mathrm{b}}$ & $1.28^{\mathrm{a}}$ & $0.55^{\mathrm{c}}$ & $472^{\mathrm{b}}$ & $15.1^{\mathrm{b}}$ & $14.4^{\mathrm{a}}$ & $8.60^{\mathrm{b}}$ & $115.7^{\mathrm{b}}$ \\
\hline Pvalue & 0.0004 & 0.0573 & 0.0001 & 0.024 & 0.0402 & $<0.0001$ & 0.0302 & 0.0114 & 0.027 & 0.0002 & 0.0016 \\
\hline Rootstock & \multicolumn{7}{|c|}{$\left(\mathrm{g} D W k g^{-1}\right)$} & \multicolumn{3}{|c|}{$\left(\mathrm{mg} \mathrm{DW} \mathrm{kg}{ }^{-1}\right)$} & \\
\hline Cherry & $7.82^{\mathrm{a}}$ & 0.59 & $1.45^{\mathrm{c}}$ & $4.68^{b}$ & $0.45^{b}$ & $0.37^{\mathrm{b}}$ & $208^{a}$ & $8.60^{b}$ & $7.63^{\mathrm{b}}$ & $7.68^{\mathrm{a}}$ & 122 \\
\hline Apple & $6.81^{\mathrm{ab}}$ & 0.67 & $3.21^{\mathrm{b}}$ & $13.9^{\mathrm{a}}$ & $0.48^{b}$ & $0.47^{\mathrm{a}}$ & $65.6^{\text {b }}$ & $14.1^{\mathrm{a}}$ & $23.3^{\mathrm{a}}$ & $4.44^{\mathrm{b}}$ & 107 \\
\hline Pear & $6.14^{\mathrm{b}}$ & 0.68 & $4.11^{\mathrm{a}}$ & $7.34^{\mathrm{b}}$ & $0.89^{\mathrm{a}}$ & $0.29^{c}$ & $144^{\mathrm{a}}$ & $11.2^{\mathrm{ab}}$ & $17.7^{\mathrm{ab}}$ & $8.58^{\mathrm{a}}$ & 118 \\
\hline$P$ value & 0.0062 & 0.0594 & $<0.0001$ & $<0.0001$ & $<0.0001$ & $<0.0001$ & 0.0027 & 0.0243 & 0.0087 & 0.0012 & 0.144 \\
\hline Variety & \multicolumn{7}{|c|}{$\left(\mathrm{g} D W k g^{-1}\right)$} & \multicolumn{3}{|c|}{$\left(\mathrm{mg} \mathrm{DW} \mathrm{kg}^{-1}\right)$} & \\
\hline Cherry & 9.16 & $0.78^{\mathrm{b}}$ & $3.25^{\mathrm{b}}$ & 4.38 & $0.64^{b}$ & $0.35^{\mathrm{b}}$ & 42.5 & $10.2^{\mathrm{a}}$ & $9.68^{\mathrm{b}}$ & 8.16 & 132 \\
\hline Apple & 9.07 & $0.92^{\mathrm{ab}}$ & $3.55^{\mathrm{b}}$ & 5.39 & $0.70^{b}$ & $0.47^{\mathrm{a}}$ & 29.7 & $12.3^{\mathrm{a}}$ & $34.9^{\mathrm{a}}$ & 9.16 & 123 \\
\hline Pear & 8.84 & $0.98^{\mathrm{a}}$ & $4.70^{\mathrm{a}}$ & 4.00 & $1.04^{\mathrm{a}}$ & $0.39^{\mathrm{b}}$ & 43.1 & $5.08^{b}$ & $29.4^{\mathrm{a}}$ & 10.7 & 123 \\
\hline Pvalue & 0.889 & 0.0375 & 0.0003 & 0.154 & 0.0008 & 0.0047 & 0.0746 & 0.0040 & 0.0003 & 0.0794 & 0.161 \\
\hline
\end{tabular}

DW, dry weight. Root and rootstock tissues were 2 -year old, while wood canopy was 1-year old. ${ }^{\mathrm{a}-\mathrm{c} W i t h i n}$ each organ, means followed by the same letter in the same column are not statistically different $(\mathrm{P}<0.05$, Tukey's honest significant difference test). 
were calculated for cherry trees (Figure 5). Removal of other nutrients was less pronounced and accounted for 22 and $29 \mathrm{~kg} \mathrm{ha}^{-1}$ for $\mathrm{P}$ and $\mathrm{Mg}$ in pear trees, respectively, while for the same elements the amount did not exceed $10 \mathrm{~kg} \mathrm{ha}^{-1}$ in the other species (Figure 5).

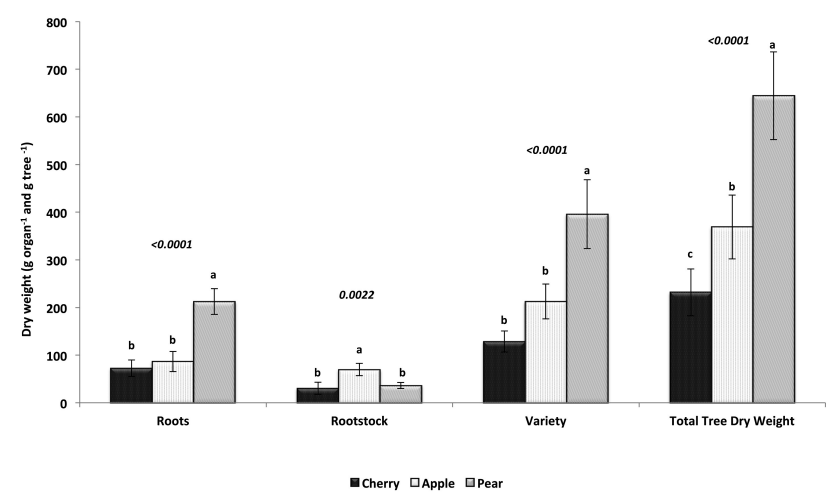

Figure 1. Organ dry biomass partitioning by nursery cherry, apple and pear trees. Roots and rootstock tissues were 2-year old while wood canopy was 1-year old. Within each organ, columns with different letters indicate statistical difference among species ( $\mathbf{P} \leq \mathbf{0 . 0 5}$ Tukey's test). Bars indicate confidence interval at $\mathbf{9 5 \%}$.

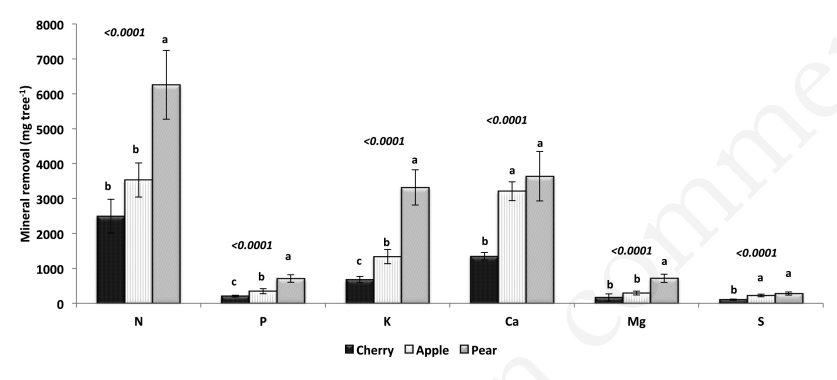

Figure 2. Macronutrients removed $\left(\mathrm{mg} \mathrm{tree}^{-1}\right)$ by nursery cherry, apple and pear trees. Within each macronutrient, columns with different letters indicate statistical difference among species ( $\mathbf{P} \leq \mathbf{0 . 0 5}$ Tukey's test). Bars indicate confidence interval at $\mathbf{9 5 \%}$.
Among micronutrients, Fe was the most required $\left(\sim 3 \mathrm{~kg} \mathrm{ha}^{-1}\right)$ independently of the species (Figure 6). B removal ranged between 1.2 and $2.4 \mathrm{~kg} \mathrm{ha}^{-1}\left(80,40\right.$ and $30 \mathrm{mg}^{-1} \mathrm{tree}^{-1}$ for pear, apple and cherry, respectively) whereas $\mathrm{Mn}, \mathrm{Cu}$ and $\mathrm{Zn}$ accounted for few hundred $\mathrm{g} \mathrm{ha}^{-1}$, irrespective of the species (Figure 6).

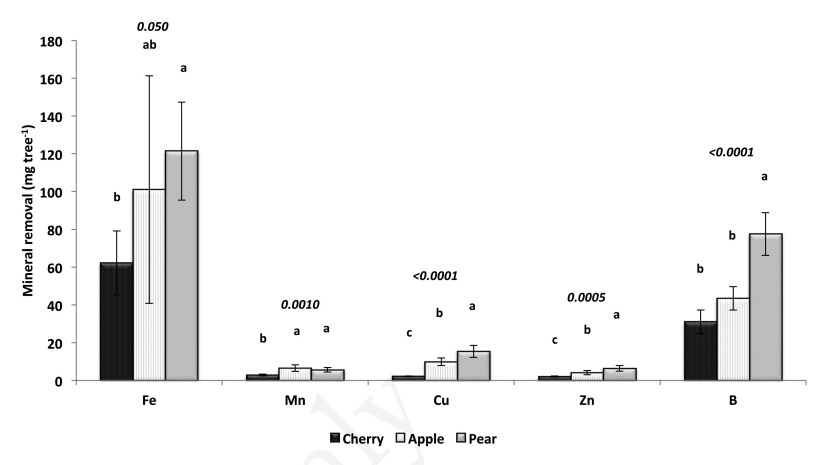

Figure 3. Micronutrients removed ( $\left.\mathrm{mg} \mathrm{tree}^{-1}\right)$ by nursery cherry, apple and pear trees. Within each micronutrient, columns with different letters indicate statistical difference among species ( $\mathbf{P} \leq \mathbf{0 . 0 5}$ Tukey's test). Bars indicate confidence interval at $\mathbf{9 5 \%}$.

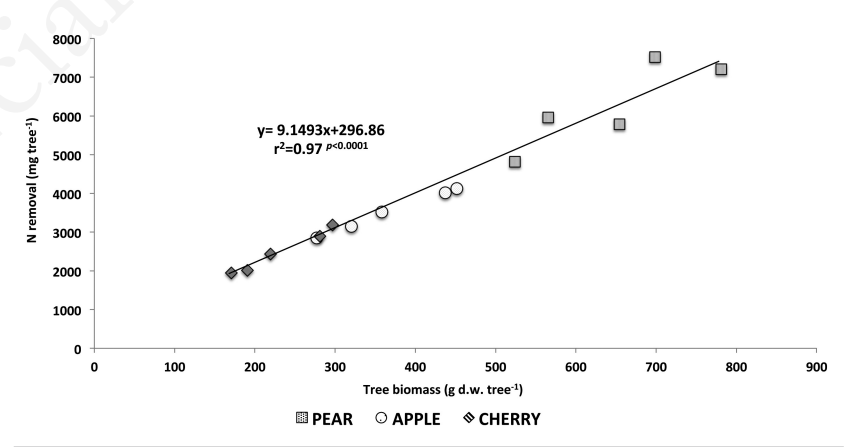

Figure 4. Correlation between tree dry biomass and nitrogen removed by nursery cherry, apple and pear trees. The line reports the trend of the three species.

Table 3. Pearson correlation between total plant dry biomass and total macro- and micronutrients removed by cherry, pear and apple nursery trees.

\begin{tabular}{|c|c|c|c|c|c|c|c|c|c|}
\hline \multirow[t]{2}{*}{ Element } & \multicolumn{3}{|c|}{ Cherry } & \multicolumn{3}{|c|}{ Pear } & \multicolumn{3}{|c|}{ Apple } \\
\hline & y & $\mathbf{R}^{2}$ & P values & y & $\mathbf{R}^{2}$ & P values & $\mathbf{y}$ & $\mathrm{R}^{2}$ & $P$ values \\
\hline \multicolumn{10}{|c|}{ Macronutrients } \\
\hline $\mathrm{N}$ & $9.7525 x+234.9$ & 0.9812 & 0.0011 & $9.1703 x+346.44$ & 0.7354 & 0.0631 & $7.2812 x+845.05$ & 0.9856 & 0.0001 \\
\hline$P$ & $0.5252 x+84.299$ & 0.8554 & 0.0244 & $1.0995 x+1.5699$ & 0.8914 & 0.0157 & $1.0569 x-43.63$ & 0.9389 & 0.0065 \\
\hline $\mathrm{K}$ & $1.7701 x+268.69$ & 0.9360 & 0.0070 & $5.2526 x-68.105$ & 0.9099 & 0.0118 & $2.9086 x+263.61$ & 0.9226 & 0.0094 \\
\hline $\mathrm{Ca}$ & $-1.0133 x+1578.9$ & 0.2239 & 0.4208 & $6.4798 x-538.76$ & 0.7077 & 0.0741 & $3.8012 x+1806.8$ & 0.878 & 0.0188 \\
\hline $\mathrm{Mg}$ & $0.1507 x+132.3$ & 0.5102 & 0.1753 & $1.1356 x-16.102$ & 0.8075 & 0.0381 & $0.6468 x+53.73$ & 0.6479 & 0.1003 \\
\hline S & $0.3425 x+23.965$ & 0.9834 & 0.0009 & $0.4518 x-10.629$ & 0.8065 & 0.0385 & $0.5863 x+8.7238$ & 0.9704 & 0.022 \\
\hline \multicolumn{10}{|c|}{ Micronutrients } \\
\hline B & $0.127 x+1.568$ & 0.9884 & 0.0005 & $0.1132 x+4.5605$ & 0.8459 & 0.0270 & $0.0884 x+10.865$ & 0.905 & 0.0128 \\
\hline $\mathrm{Fe}$ & $-0.2983 x+131.3$ & 0.7497 & 0.0578 & $0.1475 x+26.364$ & 0.2741 & 0.3653 & $0.4222 x-54.674$ & 0.2203 & 0.4251 \\
\hline $\mathrm{Mn}$ & $-0.0082 x+4.7807$ & 0.7022 & 0.0767 & $0.0095 x-0.4797$ & 0.5559 & 0.1472 & $0.0177 x-0.0369$ & 0.4827 & 0.1932 \\
\hline $\mathrm{Cu}$ & $0.002 x+1.6915$ & 0.2738 & 0.3582 & $0.0307 x-4.4244$ & 0.7992 & 0.0407 & $0.0128 x+5.147$ & 0.1858 & 0.4689 \\
\hline $\mathrm{Zn}$ & $0.0062 x+0.5819$ & 0.8744 & 0.0196 & $0.0145 x-2.9263$ & 0.7637 & 0.0525 & $0.0159 x-1.772$ & 0.9223 & 0.0095 \\
\hline
\end{tabular}




\section{Discussion}

Genetic source and tree architecture significantly affected tree biomass partitioning. These differences were driven, other than by the vegetative behaviour, the age of the rootstocks ( 2 and 3 -year old for cherry and pome trees, respectively) or the grafting compatibility, more likely by the reiterate application of benzyladenine mixed with gibberellins (i.e. GA4 and GA7) that were applied only to pome fruit trees with the aim to promote lateral shoot formation, as usually reported for these species (Palmer et al., 2011). The interactions of such factors mirrored the biomass partitioning. Santa Maria, the pear variety adopted in our study, is described as highly vigorous cultivar with a good compatibility when grafted onto quince (Ikinci et al., 2014) while apple G. Delicious and the Hungarian cherry Alex ${ }^{\mathrm{TM}}$ are of medium (Barritt et al., 1996) and low (Bassi, 2010) vigour, respectively. Despite the same age, roots of the dwarfing quince Adams (widely used as a rootstock for pear) showed a significantly higher biomass development compared to EMLA $9(+145 \%)$ and, as expected, compared to the 1-year younger Gisela ${ }^{\circledR} 6(+154 \%)$. This indicates that the pear variety was sustained by a well-developed root system while the vigour of apple was most likely reduced by the adopted rootstocks. Although dwarfing rootstocks are worldwide adopted to control tree size in intensive commercial orchards (Gregory et al., 2013), it is worth to mention that within each species, different grafting combinations, in terms of genetic materials, will likely affect the results we observed in this study, thereby estimations should be adapted to the peculiar conditions.

Given that concentration among species resulted within the same order of magnitude, differences observed in tree nutrient removal were mainly driven by the tree biomass, as showed by the relationship between nutrient removal and tree biomass, explaining most of the observed responses.

Consequently, pome fruit trees resulted more nutrient demanding than cherry, despite the higher density of the latest $(40,000 \mathrm{vs}$ 30,000 trees $h^{-1}$ ). Despite trees were non-bearing and characterised by a limited dry biomass, the estimated amount of minerals removed by 1 ha nurseries is higher compared to bearing trees of the same species grown in commercial orchards located in the same area (Sorrenti, 2006; Sorrenti and Rombolà, 2006; Toselli et al., 2006; Tagliavini and Quartieri, 2008). Our findings are then in agreement with results proposed by Neto et al. (2008), who esti- mated that $\mathrm{N}$ requirements of young pear cv. Rocha grafted on quince BA29 trees were 3, 5 and $14 \mathrm{~g} \mathrm{~N}$ tree $^{-1}$ over the first 3 years after planting. The same authors found that $\mathrm{N}$ requirements increased exponentially with tree age and were mainly correlated with the increase of trunk biomass (which represented the main $\mathrm{N}$ storage organ).

The high rate of nutrients removed in our experiment is a consequence of the ultra-high density adopted in nurseries and to the fact that trees are fully removed at the end of each growth cycle. However, while the amount of nutrients removed by the wood canopy coincide with the mineral uptake of the current season, the amount we found for rootstocks (including roots) represents the cumulative amount absorbed in 2 and 3 seasons for cherry and pome fruit species, respectively.

Nevertheless, for Gisela ${ }^{\circledR} 6$, the amount of nutrients removed before transferring the acclimated plantlets in the open-field nursery is negligible compared to the subsequent uptake. Similarly, the amount of nutrients removed by rooted lignified shoots (M9 and quince Adams) generated in the mound layering was probably scarce. However, as Gisela $6^{\circledR}$ rootstocks are grafted in the same season of their production while pome fruit species are 1-year older (rootstocks grown 1 year in the mound layering), the amount of nutrients absorbed by the entire rootstock (including roots) of a ready-to-plant tree is a consequence of two consecutive growing seasons in the nursery, irrespective of the species.

So that, the nutrient requirements we calculated per tree may appear overestimated, as part of the nutrients we measured were immobilised in the perennial structure of the rootstock in the previous growing seasons. Nevertheless, as the 1-year old canopy mostly contributed ( $>50 \%)$ to the total tree dry biomass, the mineral absorption of the ungrafted rootstocks (the growing season in the nursery previous grafting in the case of pome fruit species), should be less than $25 \%$ of the total amount.

On the other hand, we underline that the rate of nutrients consumed by the biomass of the removed shoots (aerial part of the rootstock after grafting, as well as that of the suckers) and by leaves was not considered in this study. However, leaves and shoots remain in the nursery, as the latter are mechanically chipped and incorporated into the soil. Nevertheless, although such fractions do not represent a net loss from the agroecosystem as the minerals return to the soil after mineralisation (Tagliavini et al., 2007), absorbed rates should be considered in the fertilisation schedules.

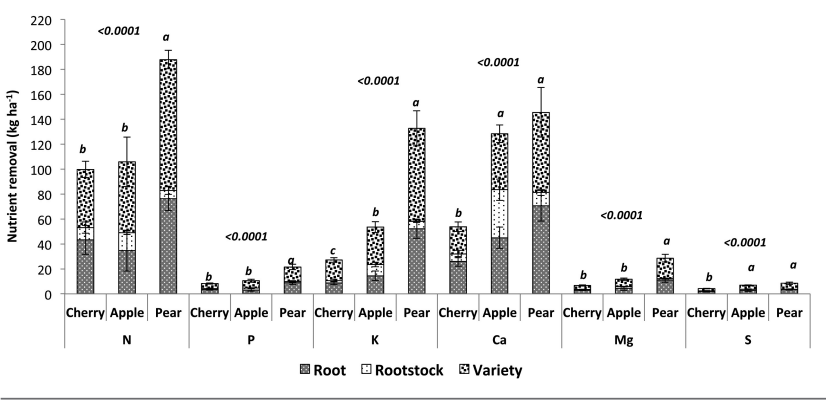

Figure 5. Macronutrients removed $\left(\mathrm{kg} \mathrm{ha}^{-1}\right)$ by nursery cherry, apple and pear tree organs. Root and rootstock tissues were 2year old, while wood canopy was 1 -year old. Within each mineral, columns with different letters indicate statistical difference among the species total removal ( $\mathbf{P} \leq \mathbf{0 . 0 5}$ Tukey's test). Bars indicate confidence interval at $95 \%$.

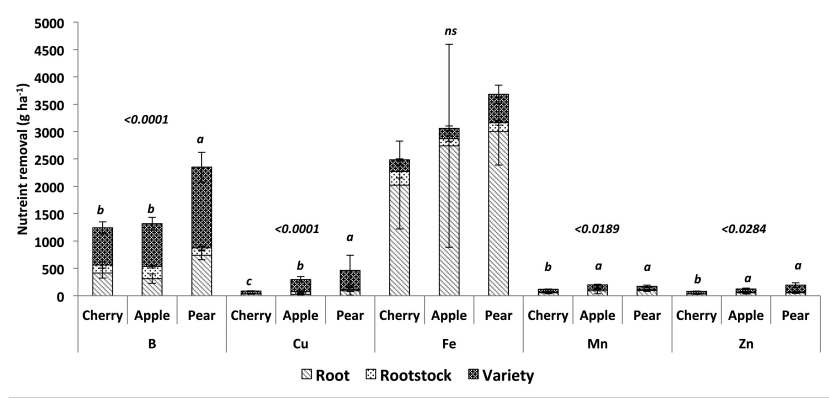

Figure 6. Micronutrients removed $\left(\mathrm{g} \mathrm{ha}^{-1}\right)$ by nursery cherry, apple and pear tree organs. Root and rootstock tissues were 2year old, while wood canopy was 1 -year old. Within each mineral, columns with different letters indicate statistical difference among the species total removal ( $\mathbf{P} \leq \mathbf{0 . 0 5}$ Tukey's test). Bars indicate confidence interval at $95 \%$. 
$\mathrm{N}$ was the most removed element by all the 3 grafting combinations, as it represents the most important nutrient for young nonbearing trees. Although $\mathrm{N}$ must be not limiting in the nursery growing substrate, it requires accurate management as its mineral forms (i.e. $\mathrm{NO}_{3}-\mathrm{N}$ ) in soil are scarcely retained by colloids, especially in sandy and poorly structured soils (as often preferred for nurseries), with risks of groundwater potential pollution.

Based on these evidences, we recommend to split the total $\mathrm{N}$ rate in several applications (e.g. by fertigation) to assure adequate mineral $\mathrm{N}$ availability to plants without excess, increasing thereby the $\mathrm{N}$ use efficiency and avoiding detrimental economic and ecological effects.

The relatively high amount of Fe absorbed by plants confirms that Fe nutrition must be adequately managed particularly in alkaline-calcareous soils, which are prone to limit Fe availability for plants (Sorrenti et al., 2011). In such conditions, the supply of organic amendments before the establishment of the nursery plots or the adoption of synthetic Fe-chelates fertilisers may result effective in managing Fe-nutrition of young trees.

Considering the limited amount required, the supply of micronutrients in the nursery does not seem to pose particular concerns as it is provided through the reiterate use of foliar-applied pesticides, often based on $\mathrm{Zn}, \mathrm{Mn}$ and especially $\mathrm{Cu}$ or $\mathrm{S}$. It is worth mentioning that our estimates are referred to the specific site, density and climate conditions of the nursery, thereby fertilisation strategies in other conditions should be adapted.

\section{Conclusions}

Although in this study pome fruit species showed higher nutrient removal compared to cherry trees, we believe that this does not indicate that they are more nutrient demanding compared to stone fruit species, rather the amount of nutrient required is a matter of plant vigor. The amount of nutrient uptaken by trees was directly related to the tree growth and dry biomass, thus depending on the grafting combination, soil fertility, climate, etc.

\section{References}

Barritt BH, Konishi BS, Dilley MA, 1996. Tree size, yield and biennial bearing relationships with 40 apple rootstocks and three scion cultivars. Proc. $6^{\text {th }}$ International Symposium on Integrated Canopy, Rootstock, Environmental Physiology in Orchard Systems, Wenatchee, Washington and Penticton, British Columbia, USA and Canada, 451:105-12.

Bassi G, 2010. Le nuove varietà: un grande passo in avanti verso la migliore qualità. Rivista di Frutticoltura 5:14-21.

Bi G, Scagel CF, Fuchigami LH, 2004. Effects of spring soil nitrogen application on nitrogen remobilization, uptake, and partitioning for new growth in almond nursery plants. J. Hortic. Sci. Biotech. 79:431-6.

Bielicki P, Czynczyk A, Nowakowski S, 2002. Influence of plant material quality on growth and yield of two apple cultivars. Hortic. Veg. Grow. 21:33-8.

Castle WS, Rouse RE, 1990. Total mineral nutrient content of Florida citrus nursery plants. Proc. Fla. State Hort. Soc. 103:42-3.

Civi-Italia, 2015. Il comparto vivaistico reclama attenzione e coinvolgimenti decisionali con le istituzioni. Rivista di
Frutticoltura 12:3-5.

Gregory PJ, Atkinson CJ, Bengough AG, Else MA, FernándezFernández F, Harrison RJ, Schmidt S, 2013. Contributions of roots and rootstocks to sustainable intensified crop production. J. Exp. Bot. 64:1209-22.

Ikinci A, Bolat I, Ercisli S, Kodad O, 2014. Influence of rootstocks on growth, yield, fruit quality and leaf mineral element contents of pear cv 'Santa Maria' in semi-arid conditions. Biol. Res. 47:1.

Kapłan M, Baryła P, 2006. The effects of growth regulators on the quality of two-year-old apple trees of "Sampion" and "Jonica" cultivars. Acta Sci. Pol. Hortorum Cultus 5:79-89.

Kingston HM, 1988. EPA IAG DWI-393254-01-0 January 1March 31, Quarterly Report 1988. Environmental Protection Agency, Washington, DC, USA. Available from: www.sampleprep.duq.edu/dir/3051method.html

Malik V, Timmer VR, 1998. Biomass partitioning and nitrogen retranslocation in black spruce seedlings on competitive mixed wood sites: a bioassay study. Can. J. For. Res. 28:206-15.

Millard P, 1995. Internal cycling of nitrogen in trees. Acta Hortic. 383:3-14

Moghadam EG, Zamanipour M, 2013. Induction of lateral branching in Sweet Cherry (Prunus avium L cvs"Siah Mashhad" \& "Dovomras") trees in nursery. J. Agric. Sci. 5:23.

Neto C, Carranca C, Clemente J, de Varennes A, 2008. Nitrogen distribution, remobilization and re-cycling in young orchard of non-bearing 'Rocha'pear trees. Sci. Hortic. 118:299-307.

Palmer JW, Seymour SM, Diack R, 2011. Feathering of 'Doyenné du Comice' pear in the nursery using repeat sprays of benzyladenine and gibberellins. Sci. Hortic. 130:393-7.

Schuman GE, Stanley AM, Knudsen D, 1973. Automated total nitrogen analysis of soil and plant samples. Soil Sci. Soc. Am. J. 37:480-1.

Sorrenti G, 2006. La gestione idrico-nutrizionale nella melicoltura moderna. Phytomagazine 52:53-64.

Sorrenti G, Rombolà AD, 2006. La fertilizzazione del pero nella frutticoltura sostenibile. Italus Hortus 13:44-5.

Sorrenti G, Toselli M, Marangoni B, 2011. Effectiveness of Amaranthus retroflexus in preventing $\mathrm{Fe}$ chlorosis in pear trees. Soil Sci. Plant Nutr. 57:813-22.

Tagliavini M, Quartieri M, 2008. I fabbisogni nutrizionali del pero per la definizione del piano di fertilizzazione. Italus Hortus 15:131-7.

Tagliavini M, Tonon G, Scandellari F, Quinones A, Palmieri S, Menarbin G, Gioacchini P, Masia A, 2007. Nutrient recycling during the decomposition of apple leaves (Malus domestica) and mowed grasses in an orchard. Agric. Ecosyst. Environ. 118:191-200.

Timmer VR, Aidelbaum AS, 1996. Manual for exponential nutrient loading of seedlings to improve outplanting performance on competitive forest sites. Northern Ontario Development Agreement's Northern Forestry Program, Great Lakes Forestry Centre, Sault Ste. Marie, ON, Canada. Available from: www.cfs.nrcan.gc.ca/pubwarehouse/pdfs/9567.pdf

Toselli M, Marangoni B, Tagliavini M, Rombolà AD, Quartieri M, Baldi E, Malaguti D, Sorrenti G, Marcolini G, 2006. La fertilizzazione delle drupacee. Notiziario Tecnico 74:7-65.

van den Driessche R, 1980. Health, vigour and quality of conifer seedlings in relation to nursery soil fertility. Proc. North American Forest Tree Nursery Soil Workshop. State University New York, College of Environmental Science and Forestry, Syracuse, NY, USA, pp. 100-20. 